\title{
PENANAMAN NILAI-NILAI DASAR HUMANIS RELIGIUS ANAK USIA DINI KELUARGA PERKOTAAN DI TK ISLAM TERPADU
}

\author{
${ }^{1)}$ Seniati Sutarmin, ${ }^{2)}$ Darmiyati Zuchdi, ${ }^{3)}$ Siti Partini Suardiman \\ ${ }^{1)}$ FKIP Universitas Sarjana Wiyata Tamansiswa, ${ }^{2,3)}$ Universitas Negeri Yogyakarta \\ ${ }^{1)}$ senny.saleh@yahoo.co.id
}

\begin{abstract}
Abstrak
Penelitian ini bertujuan untuk mendeskrepsikan penanaman nilai-nilai dasar humanis religius di TK Islam Terpadu Full Day School dengan metode kualitatif naturalistik. Subjek penelitian adalah kepala sekolah, guru, karyawan, orang tua peserta didik, dan pengurus yayasan. Hasil penelitian sebagai berikut: (1) tujuan penanaman nilai-nilai dasar humanis religius, yaitu mewujudkan generasi berakhlak mulia yang kuat iman dan ilmu; (2) metodenya BCM (bermain, cerita, menyanyi), tausyiah, pemberian nasihat pekanan, pembiasaan, dan keteladanan; medianya barang, orang, situasi sosial, dan permainan interaktif nonelektronik; (3) partisipasi orang tua dengan memberikan materi, memantau, mengevaluasi nasihat pekanan, dan melalui Pokja POMG (komite sekolah) dengan bersama-sama mencari solusi saat terjadi hambatan penanaman nilainilai dasar humanis religius; (4) keselarasan pemaknaan antara orang tua dan sekolah tentang nilai-nilai dasar humanis religius didukung kesamaan agama, etnis, dan filosofi Jawa; (5) perilaku anak di sekolah dan di rumah semakin baik setelah mendapatkan penanaman nilai-nilai dasar humanis religius.
\end{abstract}

Kata kunci: nilai humanis religius, akhlak mulia, TK Islam Terpadu

\section{IMPLANTING BASIC RELIGIOUS HUMANIST VALUES IN EARLY AGE CHILDREN OF URBAN FAMILY IN INTEGRATED ISLAMIC KINDERGARTEN}

\author{
${ }^{1)}$ Seniati Sutarmin, ${ }^{2)}$ Darmiyati Zuchdi, ${ }^{3)}$ Siti Partini Suardiman \\ ${ }^{1)}$ FKIP Universitas Sarjana Wiyata Tamansiswa, ${ }^{2,3)}$ Universitas Negeri Yogyakarta \\ ${ }^{1)}$ senny.saleh@yahoo.co.id
}

\begin{abstract}
This research is aimed to describe the implant of basic humanist religious values in integrated Islamic kindergarten - a full day school using the naturalistic qualitative method.The subjects of the research are principals, teachers, administration staffs, parents, and school committee. Results of the research are: (1) the aim of implanting basic humanist religious values is to create generation with noble character that has strong faith and knowledge; (2) the method is PSS (playing, story-telling, singing), tausyiah, weekly advice session, habituation, and exemplary; the mediums are things, people, social situation, and interactive non-electric toys; (3) parents participation is by giving materials, monitoring, evaluating weekly advice session, through school committee by finding out solutions when obstacles happen in implanting basic humanistic religious values; (4) harmony in giving meaning activity between parents and school about basic humanist religious values which are supported by sameness of religion, ethnic, and Javanese philosophy; (5) children's attitude at school and home is getting better after the implant of basic humanist religious values.
\end{abstract}

Keywords: value of human religious, noble character, integrated Islamic kindergarten 


\section{PENDAHULUAN}

Bangsa Indonesia saat sekarang sedang galau menghadapi fenomena sosial negatif akibat perubahan gaya hidup, tata cara pergaulan, perubahan sistem kemasyarakatan, dan hal-hal lain yang mudah memicu terjadinya masalah sosial yang muncul disegala bidang. Banyak masalah sosial yang terjadi di perkotaan dan mengindikasikan bahwa masyarakat kota dalam tanda kutip sedang mengalami demoralisasi. Disebutkan demikian, karena secara umum kuantitas dan kualitas kriminalitas di kota semakin meningkat, seperti: penyuapan, korupsi, penipuan dengan berbagai modus, pencurian, penganiayaan, pemerkosaan disertai pembunuhan, dan pengerusakan fasilitas umum dengan cara anarkis. Tindakan demoralisasi tersebut sangat mungkin bersumber dari kualitas akhlak dan perilaku individu atau kelompok manusia yang rendah dan rusak akibat yang bersangkutan saat masih usia dini tidak atau kurang mendapatkan pedidikan nilai melalui penanaman nilai-nilai dasar humanis religius.

Secara empiris manusia yang ketika kanak-kanak cukup mendapatkan penanaman nilai-nilai dasar humanis religius dan keteladanan perilaku yang baik dari orang tua/orang dewasa, kepribadiannya cenderung menjadi lebih baik. Sebaliknya manusia yang ketika masih kanak-kanak kurang mendapatkan keteladannan perilaku yang baik dari orang tua/ orang dewasa, kepribadiannya cenderung menjadi kurang baik, dalam bentuk melakukan tindakan sosial menyimpang. Sumber penyimpangannya banyak berkaitan dengan krisis moral spiritual dari yang bersangkutan yang terbangun sejak ia masih kanak-kanak.

Individu atau kelompok orang berakhlak rendah dan berperilaku rusak saat sekarang lebih banyak ada di kota, relevan dengan kondisi masyarakat kota yang kompleks, terbuka, bebas, kompetitif, dan cenderung individual. Perilaku yang menunjukkan ahklak rendah dan rusak telah melanda semua unsur dalam masyarakat kota, meliputi unsur jenis kelamin, usia, sampai dengan strata dan peran sosial. Dari unsur jenis kelamin, tindakan yang bersumber dari akhlak rendah dan perilaku rusak dilakukan oleh laki-laki mau pun perempuan. Dari unsur usia, dilakukan orang dewasa, remaja, hingga anakanak. Dari unsur stratifikasi dan peran sosial, dilakukan oleh pejabat tinggi di ibukota, pejabat dan tokoh masyarakat di daerah, sampai warga masyarakat biasa di perkotaan.

Seiring dengan pergeseran nilai dan norma sosial masyarakat kota yang menjauh dari kekeluargaan dan berdinamika era global, ditinjau dari dimensi pertumbuhan, perkembangan, dan pendidikan anak usia dini telah memasuki tahap memprihatinkan. Keprihatinan menyangkut anak usia dini keluarga perkotaan yang setiap hari semakin bebas menonton TV dengan berbagai materi tayangan yang beresiko besar bagi pembentukan kepribadian dan perilakunya. Hasil penelitian Chairen (Masruri, 2011, p.89) menunjukkan bahwa tidak banyak hal lain dalam kebudayaan yang mampu menandingi kemampuan TV dalam menyentuh hati anak-anak, mempengaruhi cara berpikir, dan berperilaku mereka.

Keprihatinan yang lain adalah bahwa anak usia dini keluarga perkotaan tidak dapat sehari penuh merasakan kebersamaan dengan orang tua mereka, hal ini merupakan akibat dari kesibukan atau tugas orang tua di luar rumah sebagai tanggung jawab hidup dan tuntutan perkembangan zaman. Anak usia dini keluarga perkotaan pada waktu siang banyak bersama pembantu rumah tangga, pengasuh khusus (baby sitter) atau berada pada lembaga pendidikan nonformal, yaitu: Taman Penitipan Anak (TPA), Kelompok Bermain (KB) atau Play Group. Anak usia dini keluarga perkotaan yang dimasukkan pada lembaga formal prasekolah berada di Taman KanakKanak (TK), yaitu TK biasa atau TK full day school, TK umum atau TK Islam Terpadu (IT) full day school.

Kenyataan bahwa mayoritas penduduk Indonesia, termasuk kota yogyakarta dan sekitarnya adalah pemeluk agama Islam, dan telah banyak yang menyadari pentingnya pendidikan bagi anak usia dini, maka TK IT Full Day School merupakan pemenuhan kebutuahn yang substansial bagi pendidikan anak usia dini, meskipun secara ekonomis biaya yang harus ditanggung orang tua lebih mahal dibandingkan dengan TK Islam biasa. Keluarga perkotaan cenderung lebih memilih menyekolahkan anaknya di TK IT Full Day School.

Kehadiran TK IT full day school di kota memang menguntungkan keluarga perkotaan, khususnya keluarga perkotaan yang suamiisteri bekerja di luar rumah. Keuntungan per- 
tama mengenai waktu sekolah di TK IT full day school yang sama dengan waktu orang tua bekerja, yaitu antara pukul 08.00-15.00. Selama orang tua bekerja di luar rumah, anak usia dini mereka menjadi peserta didik TK IT full day school, mereka mendapat pendidikan nilai, sehingga akhlaknhya terdidik lebih terpola daripada mereka yang berada di rumah bersama kakek-nenek, saudara dekat atau pembantu rumah tangga. Keuntungan kedua dari TK IT full day school adalah anak usia dini dapat berinteraksi dalam seting sosial yang memungkinkan mereka dapat mengimplementasi nilai-nilai yang diperoleh pada komunitas sebaya di lingkungan sekolah lebih lama. Keuntungan ketiga adalah bahwa anak usia dini keluarga perkotaan mendapat pelatihan psikomotorik sesuai dengan tingkat pertumbuhan dan perkembangannya.

Menurut kajian rumpun keilmuan pendidikan yang tertuang dalam Nation Association for The Education of Young Children (NAEYC), Bredekamp (1987) menjelaskan anak usia dini adalah anak berusia 0-8 tahun, terdiri dari: Infant (0-1 tahun); Toddler (2-3 tahun); Preschool/Kindergarten children (3-6 tahun); Early Primary School (6-8 tahun). Pengertian dan batasan usia tersebut sering digunakan untuk merujuk anak yang belum mencapai usia sekolah, kemudian bagi masyarakat dipergunakan sebagai dasar menentukan tipe sekolah.

Masa usia dini merupakan masa kanakkanak yang identik dengan masa spesial tumbuh dan berkembang (Sudjud, 1998, p.17). Wujud pertumbuhan adalah perubahan fisik dari kecil menjadi besar, wujud perkembangan dari belum mengetahui apa-apa menjadi mengetahui berbagai hal, belum dapat berbicara dengan bahasa tertentu menjadi dapat berbicara dengan bahasa tertentu. Sochiler dan Spenser (Martuti, 2008, p.3) menjelaskan bahwa perkembangan bahasa anak usia dini sangat menakjubkan, tidak hanya untuk berkomunikasi dalam bermain, tetapi juga untuk pemahaman, pengorganisasian, dan pemeranan dalam aturan permainan. Menurut teori surplus energi oleh Sochiler dan Spenser, kegiatan bermain, seperti: berlari, melompat, bergulingan, menjadi ciri khas anak kecil dan anak binatang dengan tujuan yang berbeda. Pada anak manusia dan anak binatang dengan tingkat evolusi tinggi, bermain terjadi akibat energi yang berlebihan, sedang pada anak binatang dengan evolusi rendah (serangga, katak, dan sejenisnya), energi tubuh dimanfaatkan untuk mempertahankan hidup.

Meyke S.T (Martuti, 2008, p.39) menguraikan manfaat bermain bagi anak adalah: (1) mengembangkan fisik, karena bermain melibatkan gerakan tubuh, maka fisik anak menjadi sehat, otot-otot menjadi kuat, energi berlebihan tersalurkan, anak menjadi lebih tenang; (2) mengembangkan kepribadian, dengan bermain anak menyalurkan tenaga, menyalurkan ketegangan, hatinya menjadi puas, lega, dan lebih rileks; (3) menyadari kelebihan dan kekurangan diri, timbul harga diri, karena merasa memiliki kompetensi tertentu; (4) mengembangkan aspek kognitif, anak belajar mengenal warna, ukuran, bentuk, arah, dan sebagainya; (5) mengembangkan kreativitas dan daya cipta, karena bermain merupakan sumber pengalaman dan uji coba; (6) berlatih bahasa tubuh dan kata-kata yang diucapkan temannya, sekaligus mengungkapkan keinginannya, dan (7) untuk mengasah ketajaman indera penglihatan, pendengaran, penciuman, pengecapan, dan perabaan. Permainan menggembirakan anak, karena tidak mempunyai tujuan ekstrinsik, motivasi anak dalam bermain subjektif dan tidak mempunyai tujuan praktis, karena permainan dilakukan anak secara spontan, suka rela, dipilih secara bebas. Setiap TK secara umum telah menyelenggarakan pendidikan anak usia dini melalui berbagai permainan yang menggembirakan, namum belum tentu permainan tersebut telah sesuai dengan pertumbuhan dan perkembangan anak usia dini keluarga perkotaan.

Anak usia dini keluarga perkotaan adalah anak dari keluarga yang tinggal di wilayah perkotaan dan sekitarnya. Orang tua perkotaan cenderung merasa banyak diuntungkan oleh TK IT full day school, sehingga menjadi tidak kritis, tidak banyak mempertimbangkan tentang konsep yang melandasi, metode dan media apa yang digunakan, dan sejauh mana TK tersebut telah berhasil melaksanakan penanaman nilai-nilai dasar humanis religius kepada peserta didiknya. David Weikart (Sulistyaningsih, 2008, p.14) menyatakan bahwa TK full day school yang berhasil memiliki tiga faktor pendukung utama, yaitu: faktor kurikulum, keterlibatan orang tua, dan kualitas program yang dilaksanakan. Namun dalam kenyataan masih banyak orang tua perkotaan belum memahami 
kurikulum TK, belum banyak ikut berperan pada kegiatan TK, dan belum banyak yang terlibat secara langsung pada program dan pelaksanaan penanaman nilai-nilai dasar humanis religius, kebanyakan orang tua tidak memasalahkan program, pelaksanaan dan hasil penanaman nilai-nilai dasar humanis religius.

Pendidikan anak usia dini yang penyelenggaraannya sebelum jenjang pendidikan dasar, formal, dan/atau informal (Pasal 28 UU RI Nomor 20 Tahun 2003), tidak kalah pentingnya dengan pendidikan jenjang di atasnya. Pendidikan prasekolah menjadi dasar pendidikan tingkat dasar dan tingkat menengah.

Pendidikan nilai, melalui penanaman nilai-nilai dasar humanis religius secara informal memang menjadi kewajiban keluarga dalam bentuk sosialisasi primer, secara umum berlangsung sejak anak lahir hingga masuk TK. Penanaman nilai-nilai luhur yang fungsinya mendasari perilaku anak di luar rumah telah dilaksanakan oleh keluarga. Pendidikan nilai di keluarga didasari cinta kasih dan ikatan batin orang tua dengan anaknya. Anak yang fitrahnya suci dalam keluarga merupakan amanah Allah Swt kepada orang tuanya. Sebagai khalifah Allah di bumi anak harus cerdas dan berakhlak mulia, karena itu membutuhkan pendidikan nilai untuk mengembangkan akhlak, iman, keilmuan, dan keterampilan sosialnya.

Sebagai khalifah Allah yang dipercaya mengatur dunia dan seisinya, anak sejak lahir sudah membawa potensi untuk dididik, dalam bahasa agama dikatakan sebagai fitrah, tentang fitrah, Allah Swt berfirman yang artinya adalah:

Maka hadapkanlah wajahmu dengan lurus kepada agama (Allah); (Tetaplah atas) fitrah Allah yang telah menciptakan manusia menurut fitrah itu. Tidak ada perubahan pada fitrah Allah. (Itulah) agama yang lurus; tetapi kebanyakan manusia tidak mengetahui (QS Al-Rum (30): 30). Al-Quran dan terjemahannya (2001: 901).

Penelitian Cryan (1992) membuktikan efek yang luas dalam pendidikan anak usia dini dengan sistem full day school, yang menjadikan anak memiliki kedekatan dengan guru, kelebihan dalam perilaku yang positif, kesuksesan akademik, kemandirian dalam belajar, produktivitas dalam kerja, dan pengendalian emosi/rasa percaya diri. Sistem full day school cukup efektif untuk perkembangan anak usia dini. Yusuf (2000) mengatakan bahwa sistem full day school lebih efektif untuk pendidikan anak usia dini, karena selama ini mereka dipandang kurang diperhatikan aspek kognitifnya, seperti: sikap; bakat; minat; motivasi; empati; toleransi; kecerdasan spiritual (SQ), dan kederdasan emosional (EQ). Kondisi tersebut menjadikan anak kurang mandiri dan kreatif, kurang mampu berkomunikasi dengan lingkungan fisik, sosial, serta kultur dalam masyarakat. Sistem full day school pada TK akan memberikan keteladanan dengan mental persaudaraan (brotherhood), persahabatan (friendship), dan dengan metode yang dialogis, secara klasikal dan individual, dalam suasana yang menyenangkan. Namun di lapangan belum semua TK IT full day school di kota dapat melaksanakan pendidikan nilai bagi anak usia dini seperti yang dimaksudkan oleh Yusuf, karena motivasi pihak penyelenggara TK IT full day school banyak yang memperhitungkan untung dan rugi, bukan sematamata mengutamakan keberhasilan pendidikan nilai.

Bisnis TPA, PG, dan TK IT full day school di kota cenderung menguntungkan, ditunjukkan dengan jumlah TK semacam ini terus bertambah, rata-rata kelas yang dimiliki penuh, fasilitasnya diupayakan semakin baik, persaingan mendapatkan peserta didik semakin ketat, karena menjelang tahun ajaran baru berlomba-lomba membujuk keluarga perkotaan agar memilih program yang ditawarkannya, melalui promosi, diantaranya dengan memasang spanduk di berbagai sudut kota, fenomena tersebut menimbulkan beberapa masalah.

Masalah pertama, mengenai konsep dasar yang melandasi, tujuan, dan sejauh mana lembaga TK IT full day school telah berhasil melaksanakan penanaman nilai-nilai dasar humanis religius bagi peserta didiknya. Masalah kedua, menyangkut masih banyak orang tua anak usia dini perkotaan yang belum peduli pada metode dan media yang digunakan TK IT full day school untuk menanamkan nilai-nilai dasar humanis religius bagi peserta didiknya. Masalah ketiga, tentang kepedulian dan partisipasi orang tua atau 
komite sekolah pada program dan pelaksanaan penanaman nilai-nilai dasar humanis religius, karena rata-rata orang tua hanya menyerahkan sepenuhnya kepada kebijakan TK. Masalah keempat, menyangkut sejauh mana keselarasan pemaknaan orang tua dengan TK IT full day school tentang nilai-nilai dasar humanis religius. Sedangkan masalah kelima adalah tentang bagaimana hasil pelaksanaan penanaman nilai-nilai dasar humanis religius dalam wujud perubahan perilaku anak di sekolah dan di rumah setelah mendapatkan penanaman nilai-nilai dasar humanis religius.

Kebutuhan pendidikan nilai, melalui penanaman nilai-nilai dasar humanis religius bagi anak usia dini keluarga perkotaan sepertinya sudah terpenuhi dengan baik di TK IT full day school, yang rata-rata mengaku berlandaskan konsep dasar Islam, menggunakan metode dan media yang dianggap telah sesuai dengan pertumbuhan dan perkembangan anak usia dini. Namun dalam kenyataan masih banyak anak dan remaja di perkotaan perilakunya belum seperti yang diharapkan. Hal ini ditunjukkan dengan unggah-ungguh (kesantunan) anak kepada orang yang lebih tua semakin berkurang, bahkan dapat dikatakan semakin menghilang dari keseharian anak-anak keluarga perkotaan yang sejak dini lebih banyak mendapatkan pengaruh budaya asing dari berbagai media. Nilai-nilai kejujuran semakin mengkabur, anak berbicara dan berperilaku tidak jujur, berani membantah nasihat yang diberikan orang tua dengan sikap dan ucapan yang tidak sepantasnya, semua itu cenderung menjadi biasa.

Sistem pendidikan yang mampu mengembangkan pribadi yang memiliki karakter terpuji, yang secara sosial siap memasuki dunianya, seharusnya menjadi tujuan utama setiap institusi pendidikan di Indonesia (Zuchdi, dkk, 2013, p.1), khususnya pada institusi pendidikan formal terendah atau jenjang TK, yang rata-rata telah menempatkan karakter terpuji sebagai tujuan utama pendidikan, dalam kenyataan belum semua TK melaksanakannya secara maksimal, disebabkan pihak konsumen institusi pendidikan prasekolah lebih cenderung berharap anaknya memiliki keunggulan intelektual, berprestasi secara akademik daripada unggul karakternya. Fenomena tersebut semakin memperlemah keberadaan pendidikan nilai yang salah satu pe- laksanannya melalui penanaman nilai-nilai dasar humanis religius.

Pendekatan penanaman nilai (inculcation approach) dipandang Superka (Elmubarok, 2008, p.5) sebagai pemberian penekanan pada penanaman nilai sosial dalam diri peserta didik, tujuannya diterimanya nilai-nilai sosial tertentu oleh peserta didik, berubahnya nilainilai peserta didik yang tidak sesuai dengan nilai-nilai sosial yang tidak diinginkan. Namun disadari atau tidak pendekatan penanaman nilai telah digunakan secara meluas dalam berbagai masyarakat Indonesia, terutama untuk penanaman nilai-nilai agama dan nilainilai budaya.

Nilai dalam ranah pendidikan membantu peserta didik untuk mengembangkan pribadi yang lebih manusiawi sesuai kodrat manusia, berguna dan berpengaruh dalam masyarakatnya, bertanggung jawab dan bersifat proaktif, serta kooperatif. Menurut Driyarkara (1991, p.46) masyarakat membutuhkan pribadi-pribadi yang handal dalam bidang akademis, keterampilan, keahlian, sekaligus memiliki watak atau keutamaan yang luhur, namun tetap humanis. Kenyataannya masih banyak orang tua memasukan anaknya pada bimbingan belajar, agar kelak menang olimpiade matematika atau fisika, memasukan anaknya pada lembaga olah vocal agar nantinya dapat memenangkan Indonesia Idol yang sering digelar di TV swasta. Pendidikan nilai menjadi nomor kesekian, meskipun ada juga orang tua perkotaan yang memasukkan anaknya pada pondok pesantren, tetapi jumlahnya belum sebanding dengan jumlah orang tua yang lebih mengutamakan keberhasilan anaknya di bidang akademis, seni, dan keterampilan fisik yang aktual, bukan pada internalisasi nilai-nilai dasar ke-Islaman.

Menurut Rahman Saleh (Zulkarnain, 2008, p.7) nilai dasar dalam Islam disebut sebagai nilai dasar ubudiyah, moralitas/akhlaqul karimah, dan nilai dasar nizhamiyah/kedisiplinan. Nilai dasar ubudiyah meliputi aktivitas manusia sebagai hamba Allah Swt dan selaku khafilah-Nya di muka bumi, hakikatnya berbakti atau mengabdi kepada Allah sekaligus untuk mendapatkan ridha-Nya (QS. Az-Zariyat: 56), yang artinya: "Dan Aku tidak menciptakan jin dan manusia melainkan untuk menyembah Aku".

Nilai dasar moralitas/akhlaqul karimah merupakan inti ajaran Islam yang dibawa oleh 
Rasulullah Saw, yang tidak lain untuk membentuk akhlak manusia menjadi mulia. Rasulullah bersabda, yang artinya: "Sesungguhnya aku diutus tidak lain dalam rangka menyempurnakan akhlaqul karimah". Akhlak mendasari semua perbuatan, aktivitas, kreasi, dan karya manusia. Nilai moralitas di perkotaan sedang bergulat menghadapi nilai baru keluarga perkotaan era global.

Menurut Wirth dan Parson (Tangdilintin, 1990, p.1) keluarga perkotaan merupakan keluarga dalam proses adaptasi terhadap kehidupan modern. Keluarga perkotaan termasuk tipologi yang tidak memperlihatkan ikatan kekerabatan yang kuat, mulai terbebas dari ikatan keluarga luas, oleh Parson disebut sebagai keluarga konjugal (pasangan individu) yang terisolasi.

Sebagai orang tua dari anak usia dini, keluarga perkotaan tetap mendambakan anaknya berkepribadian Islami (shalih-shalikah). Menurut Mudjib (1999, p.133) kepribadian dalam studi Islam lebih dikenal dengan istilah syakhshiyah, berasal dari kata syakhshun yang artinya kepribadian. Kepribadian menurut Islam adalah integrasi sistem kalbu, akal, dan nafsu manusia yang menimbulkan perilaku (beriman dan beramal shalih) (QS. Asy-Syamsu: 8). Yusuf (2008, p.218) menegaskan bahwa manusia dapat berkembang menjadi seorang yang berkepribadian mulia (shalih) atau berkepribadian buruk (dolim/fasik/munafik). Kepribadian yang mana yang akan mewujud pada diri seorang anak tergantung pada kualitas pengalaman hidup sebagai hasil interaksi dan sosialisasi anak, termasuk pengalamannya di sekolah atau di TK, baik TK biasa ataupun TK IT full day school.

Penanaman nilai-nilai dasar humanis religius dengan berbagai istilah internal TK telah lama dilaksanakan, namun dalam kenyataan belum semua TK IT full day school telah melaksanakan hal tersebut dengan cara yang sebaik-baiknya. Cara penanaman nilainilai dasar humanis religius atau metode, dan media yang digunakan oleh TK IT full day school belum tentu telah sesuai dengan kebutuhan dan fase perkembangan anak usia dini, sedangkan penanaman nilai-nilai dasar humanis religius kepada anak usia dini menjadi sangat penting, karena mempengaruhi kualitas akhlak, intelektual, dan perilaku anak pada kehidupan sosialnya.
Penanaman nilai-nilai dasar humanis religius yang di dalamnya memuat berbagai aspek life skills merupakan konkretisasi dari empat pilar pendidikann yang sangat fundamental. Menurut Delors (1997, p.27) empat pilar tersebut adalah: (1) belajar mengetahui (learning to know), (2) belajar berbuat (learning to do), (3) belajar menjadi diri sendiri (learning to be), dan (4) belajar hidup bersama (learning to live together). Semua itu menjadi inti dari humanisme Islam.

Menurut Achmadi (2005, p.21) humanisme Islam adalah humanis teosentris, yaitu pandangan kemanusiaan (humanis dalam Islam), tetapi dalam bingkai keimanan kepada Tuhan Yang Maha Esa (Tauhid). Oleh karena hal itu humanis teosentris menjadi nilai inti (core of value) dari seluruh sistem nilai dalam Islam. Teosentrisme dalam Islam adalah "Tauhidi" yang berarti seluruh kehidupan berpusat pada Allah, Tuhan Yang Esa. Allah sebagai ghayatul hayat (tujuan hidup). Konsep tauhid sebagai aqidah Islam mengandung implikasi doktrinal bahwa tujuan kehidupan manusia adalah ibadah kepada Allah (QS. alDzariyat: 56) dan memikul amanah sebagai khalifah Allah di bumi (QS. al-Baqarah: 30), Yunus: 14, al-An'am: 65. Implikasi lebih lanjut dari konsep Tauhid merupakan nilai dasar dari seluruh tatanan nilai dalam Islam sebagai norma dan pedoman hidup, terutama kehidupan keberagamaan atau religiusitas seorang muslim. Namun kenyataanya masih banyak orang tua muslim belum mengetahui tujuan dan konsep dasar yang melandasi penanaman nilai-nilai dasar humanis religius yang ingin dicapai, metode dan media yang digunakan, dan sejauh mana hasil penanaman nilai-nilai dasar humanis religius terhadap perilaku anak. Beberapa masalah yang timbul dari pelaksanaan penanaman nilai-nilai dasar humanis religius di TK IT full day school membutuhkan pengkajian lebih mendalam dalam bentuk penelitian ilmiah.

\section{METODE}

Penelitian ini menggunakan pendekatan kualitatif-naturalistik. Alasan memilih pendekatan kualitatif, karena yang dihadapi peneliti di lapangan kondisi sosial alamiah (natural setting). Menurut Bogdan dan Biklen (Sugiyono, 2008, p.14) kondisi objek penelitian kualitatif-naturalistik bersifat alamiah, 
realitasnya sebagai keutuhan yang dinamis, penuh makna dengan sifat hubungan interaktif, dan merupakan konstruktif pemikiran/ interpretasi terhadap gejala secara holistik. Pendekatan penelitian ini berdasar pada filsafat fenomenologis, karena lebih mengutamakan penghayatan (verstehen).

Penentuan sumber data secara purposive dan snowball. Teknik pengumpulan data dengan wawancara mendalam, pengamatan partisipatif, dan pengumpulan dokumen. Analisis data bersifat induktif. Hasil penelitian ini lebih ditekankan pada makna daripada generalisasi.

Informan penelitian meliputi pengurus yayasan, kepala sekolah, guru, karyawan, orang tua peserta didik. Aktivitas yang diteliti adalah cara penanaman nilai-nilai dasar humanis religius kepada peserta didik. Peneliti sebagai instrumen kunci, senantiasa berusaha menjalin komunikasi dengan informan lebih dekat, akrab, serta berempati tinggi, guna memperoleh pemahaman situasi yang lebih mendalam, agar data yang diperoleh menjadi lebih luas, akurat, namun jarak dengan informan selalu dijaga agar peneliti lebih mampu mendapatkan data yang objektif dan akurat.

Prosedur penelitian dilaksanakan dengan pentahapan sebagai berikut. Tahap pertama, melakukan studi pendahuluan pada tiga TK Islam full day school dan satu TK Islam biasa, menggunakan instrumen angket, hasilnya dianalisis untuk menentukan fokus penelitian. Tahap kedua, pengumpulan data dengan teknik: (1) observasi partisipasi; (2) wawancara mendalam dengan informan, dimulai informan yang dianggap paling mengetahui seluk beluk TK IT Full Day School Mu'adz Bin Jabal Yogyakarta, yaitu kepala sekolah; ia yang menunjukkan siapa informan berikutnya yang akan diwawancarai secara mendalam, demikian seterusnya sampai data yang diperoleh jenuh, artinya tidak muncul informasi baru; (3) studi dokumen, yaitu mengumpulkan dan mengkaji berbagai dokumen tentang TK IT full day school Mu'adz Bin Jabal Yogyakarta berbentuk web, arsif, buku standar mutu, liflet, dan lain-lain. Keabsahan data dicapai dengan triangulasi sumber dan triangulasi teknik pengumpulan data. Tahap ketiga, analisis data setelah selesai di lapangan, melalui langkah-langkah penarikan kesimpulan, dilakukan dengan cara meninjau ulang atas seluruh catatan lapangan, merenungkan kembali data yang sudah diinterpretasi untuk dikembangkan menjadi kesimpulan.

\section{HASIL}

Hasil penelitian ini adalah: (1) tujuan penanaman nilai-nilai dasar humanis religius di TK IT Full Day School Mu'adz Bin Jabal Yogyakarta adalah mewujudkan generasi masa depan berakhlak mulia yang kuat iman dan keilmuannya. Konsep dasar yang melandasinya adalah Aqidah Islamiah; (2) metode yang digunakan oleh TK IT Full Day School Mu'adz Bin Jabal Yogyakarta untuk penanaman nilai-nilai dasar humanis religius adalah BCM (Bermain, Cerita, Menyanyi), taushiyah, pemberian nasihat pekanan, pembiasaan, dan keteladanan, dan medianya adalah orang, barang, situasi sosial, dan permainan interaktif nonelektronik; (3) kepedulian dan partisipasi orang tua secara perorangan dengan memberi materi nasihat pekanan, memantau, dan mengevaluasi pelaksanannya dan partisipasi secara kelompok melalui PokjaPokja POMG (Komite Sekolah), dengan mendukung dan ikut mencari solusi saat terjadi hambatan penanaman nilai-nilai dasar humanis religius; (4) ada keselarasan pemaknaan orang tua dan sekolah tentang nilai-nilai dasar humanis religius; (5) terjadi perubahan perilaku anak lebih baik di sekolah dan di rumah, setelah mendapatkan penanaman nilai-nilai dasar humanis religius.

\section{PEMBAHASAN}

Pendidikan berlandaskan Islam adalah suatu proses menuju terciptanya kualitas dan kejayaan generasi Islami masa depan. Konsep dasar yang melandasi penanaman nilai-nilai dasar humanis religius berfungsi sebagai dasar yang bermakna filosofi dalam praktik pendidikan Islam guna mewujudkan generasi berakhlak mulia yang kuat iman dan keilmuannya. Ilmu adalah syarat mendapatkan kesuksesan dunia akhirat, hal ini sesuai dengan sabda Rasulullah Saw, yang artinya: "Barang siapa yang menghendaki dunia, maka baginya ilmu. Barang siapa yang menghendaki akhirat baginya ilmu. Dan barang siapa menghendaki kebahagiaan dunia dan akhirat baginya ilmu." 
Iman dan ilmu tidak dapat dipisahkan satu sama lain. TK IT Full Day School Mu'adz Bin Jabal Yogyakarta memadukan iman dan ilmu sebagai konsep dasar yang melandasi penanaman nilai-nilai dasar humanis religius (pendidikan akhlak mulia) kepada peserta didiknya dalam bentuk: (1) keuswahan atau konsistensi aktualisasi nilai-nilai dasar humanis religius yang ditanamkan. (2) penegakan amar ma'ruf nahi munkar atau kontrol moral atas kepribadian, (3) penguasaan kontektualisasi atau kemampuan menerapkan materi nilai-nilai, dan (4) penggunakan dukungan metode dan media pendidikan yang berpusat pada kepentingan peserta didik, hal ini sesuai dengan standar mutu Sekolah Islam Terpadu (SIT, 2010, p.43).

Tujuan penanaman nilai-nilai dasar humanis religius di TK IT Full Day School Mu'adz Bin Jabal Yogyakarta adalah membangun insan masa depan berkepribadian Islami yang norma-normanya diturunkan dari ajaran Islam, bersumber pada Alquran dan Assunah, bersifat induktif-praktis, karena digali dan dirumuskan dari penelitian terhadap perilaku keseharian umat Islam. Hal ini sesuai dengan gagasanYusuf dan Nurihsan (2008, p.6) bahwa insan berkepribadian Islami berperilaku humanis berdasarkan keberagamaan (cerdas spiritual). Sesuai juga dengan pernyataan Zuchdi (2010, p.110) bahwa cerdas spiritual, dalam konteks Indonesia adalah kecerdasan religius, karena bermuatan ajaran agama. Kecerdasan emosional dan spiritual (religius) yang digali dari Islam adalah konsistensi (istiqamah), kerendahan hati (tawa$d h u$ ), totalitas (kaffah), keseimbangan (tawa$z u n$ ), integritas dan penyempurnaan (ihsan).

Metode dan media dibutuhkan untuk pelaksanaan penanaman nilai-nilai dasar humanis religius, karena nilai tidak timbul dengan sendirinya, harus ada faktor-faktor prasyarat timbulnya sebuah nilai. Hal ini sejalan dengan pernyataan Barnadib (1967, p.32) bahwa timbulnya sebuah nilai memerlukan prasyarat dan cara. Dalam pendidikan Islam dikenal berbagai metode pembelajaran akhlak mulia, selaras dengan pernyataan Nata (2010, p.153). TK IT Full Day School Mu'adz Bin Jabal Yogyakarta menggunakan metode BCM (Bermain, Cerita, Menyanyi), taushiyah, nasihat pekanan, pembiasaan, dan keteladanan. Metode-metode tersebut sejalan dengan pendapat Marjory (Aswarni Sudjud, 1998, p.5) bahwa anak usia dini dalam perkembangan yang unik, kritis, dan sibuk, membutuhkan berbagai kegiatan mental dan fisik untuk mengembangkan semua potensi kognitif, afektif, dan psikimotorik.

Kepedulian dan partisipasi orang tua pada program dan pelaksanaan penanaman nilai-nilai dasar humanis religius di TK IT Full Day School Mu'adz Bin Jabal Yogyakarta secara perorangan dengan memberikan materi nasihat pekanan, sekaligus memantau dan mengevaluasi pelaksanannya. Partisipasi orang tua secara kelompok melalui PokjaPokja POMG (Komite Sekolah). Pada aspek pengembangan fisik, Pokja POMG yang ada pada setiap kelas mempersiapkan program olahraga, seni dan lain-lain. Hal ini selaras dengan menu pembelajaran generik yang digagas Siskandar (2003, p.25) bahwa orang tua terlibat kegiatan di sekolah anak sebenarnya untuk keuntungan mereka sendiri, untuk anak-anaknya sendiri, dan untuk keuntungan mereka sendiri.

Keselarasan pemaknaan orang tua dengan sekolah tentang nilai-nilai dasar humanis religius di TK IT Full Day School Yogyakarta didukung adanya kesamaan agama (Islam), kesamaan visi mewujudkan generasi masa depan berakhlak mulia, kesamaan etnis (Jawa) yang filosofinya cenderung sama, yaitu: "wedi isin (takut mendapat malu), sungkan (segan dan hormat kepada orang lain), dan tidak suka berselisih secara terbuka". Hal ini sesuai dengan pernyataan Suseno (2009, p.122) yang menyebutkan bahwa etnis Jawa hakikatnya mencari keselarasan sosial.

Perilaku adalah segala sesuatu yang dikerjakan dan yang dikatakan oleh manusia, cerminan dari kepribadiannya yang bersifat kompleks. Konsep kepribadian Islam merupakan penampilan makhluk mulia yang memiliki struktur kompleks, meliputi jasmani, ruhani, dan nafsani. Hal ini sesuai dengan pernyataan Yusuf dan Nurihsan (2008, p.66) bahwa struktur jasmani, ruhani, dan nafsani dapat dipengaruhi oleh lingkungan. Perilaku peserta didik TK IT Full Day School Mu'adz Bin Jabal Yogyakarta berubah menjadi lebih baik di sekolah dan di rumah setelah mendapatkan penanaman nilai-nilai dasar humanis religius atau pembelajaran akhlak mulia dari lingkungan. Hal ini sesuai dengan teori Bloom (1956) yang menyatakan bahwa perilaku manusia dapat berubah setelah adanya pembel- 
ajaran. Pembelajaran akhlak mulia merubah perilaku anak menjadi lebih baik. Perubahan perilaku meliputi kawasan (domain) kognitif, afektif, dan psikomotor. Domain kognitif terdiri dari aspek intelektual atau pikiran yang merupakan domain dasar, terdiri dari pengetahuan, bentuknya pada anak adalah mengetahui hal-hal yang berkaitan dengan Allah Swt, Kitab Alquran, Malaikat, Nabi dan Rasul, shalat wajib, shalat sunnah, shalat berjama'ah, dan seterusnya. Domain afektif mengait dengan aspek emosional, minat dalam berkomunikasi sosial, santun saat bicara, mau meminta maaf jika berbuat salah, mau memberi maaf jika ada teman yang berbuat salah pada dirinya. Domain psikomotor, mengait dengan perkembangan keterampilan fisik (menggambar, mewarnai, menggunting, menempel, dan sebagainya).

Untuk mengetahui ada atau tidak adanya perubahan perilaku anak setelah mendapat penanaman nilai-nilai dasar humanis religius, perlu adanya evaluasi pendidikan nilai. Hal ini sesuai dengan pernyataan Zuchdi (2010, p.51) bahwa evaluasi pendidikan nilai perlu dilakukan untuk mengetahui ketercapaian tujuan. Evaluasi yang dimaksudkan mencakup tiga ranah: penalaran moral, evaluasi karakteristik afektif, dan evaluasi perilaku. Di TK IT Full Day School Mu'adz Bin Jabal Yogyakarta yang melakukan evaluasi penanaman nilai-nilai dasar humanis religius kepada peserta didik adalah wali kelas dibantu guru pendaping masing-masing kelas. Hasil evaluasi dilapor-kan kepada orang tua sebagai laporan perkembangan anak berbentuk Buku Raport. Sebagai bahan untuk laporan kepada yayasan Mu'adz Bin Jabal sebagai pertanggung jawaban tugas informan di lapangan.

\section{SIMPULAN}

1. Tujuan dilaksanakannya penanaman nilainilai dasar humanis religius di TK IT Full Day School Mu'adz Bin Jabal Yogyakarta adalah mewujudkan generasi berakhlak mulia yang kuat iman dan keilmuannya. Konsep dasar yang melandasi adalah Aqidah Islamiah.

2. Metode yang digunakan untuk pelaksanaan penanaman nilai-nilai dasar humanis religius di TK IT Full Day School Mu'adz Bin Jabal Yogyakarta adalah BCM (Bermain, Cerita, Menyanyi), tausyiah, pem- berian nasihat pekanan, pembiasaan, dan keteladanan, serta medianya adalah barang, orang, situasi sosial, dan permainan interaktif nonelektronik, yang terkait dan relevan dengan materi nilai-nilai dasar humanis religius.

3. Kepedualian dan partisipasi orang tua pada pelaksanaan penanaman nilai-nilai dasar humanis religius secara perorangan dengan memberikan materi nasihat pekanan, memantau, dan mengevaluasi pelaksanaanya. Partisipasi secara kelompok melalui PokjaPokja POMG (Komite Sekolah) dengan melibatkan diri secara langsung untuk mencari solusi hambatan penanaman nilainilai dasar humanis religius.

4. Ada keselarasan pemaknaan orang tua dan sekolah tentang nilai-nilai dasar humanis religius. Hal tersebut didukung adanya beberapa kesamaan, yaitu: kesamaan agama (Islam), kesamaan etnis dan filosofi (Jawa), "wedi isin" takut mendapat malu, "sungkan" segan dan menghargai orang lain, dan " tidak suka berselisih secara terbuka".

5. Ada perubahan perilaku anak semakin baik di sekolah dan di rumah setelah mendapatkan penanaman nilai-nilai dasar humanis religius. Perubahan perilaku anak di sekolah meliputi : (a) perilaku dalam aqidah, (b) perilaku dalam akhlak, (c) perilaku dalam ibadah, (d) perilaku dalam dimensi sosial, emosional, dan kemandirian. Perubahan perilaku anak di rumah ditunjukkan dengan: (a) lebih memperhatikan dan mendengarkan kata-kata orang tua, (b) dapat mengucapkan dan menjawab salam secara Islam dengan benar, (c) dapat membedakan pakaian yang menutup aurat dan tidak menutup aurat, (d) dapat berdoa sendiri.

\section{IMPLIKASI}

Implikasi hasil penelitian adalah: (1) pada metodologi penelitian, yaitu menawarkan satu alternatif dalam proses penanaman nilai-nilai dasar humanis religius untuk pembentukan kepribadian Islami bagi anak usia dini keluarga perkotaan melalui pendidikan nilai yang terintegrasi dengan berbagai kegiatan pendidikan di TK; (2) pada teoretis, yaitu agar makna nilai-nilai dasar humanis religius yang merupakan konsepsi abstrak tentang perilaku Islami bagi anak menjadi lebih jelas, 
maka memerlukan penjelasan teoretis secara gamblang dan detail, pada setiap dimensi nilai-nilai dasar humanis religius. Nilai-nilai dasar humanis religius merupakan realitas abstrak yang hanya dapat dirasakan pada diri individu sebagai pendorong dalam hidup, internalisasinya memerlukan penanaman secara sadar sejak anak usia dini, diprogram dengan baik, dikelola secara eksplisit, terfokus, dan komprehensif, sehingga dapat menghasilkan atau membentuk perilaku yang baik, seperti yang diharapkan. Sekolah jenjang TK dan orang tua sebagai fungsionalis dan subjek aktif penanaman nilai-nilai dasar humanis religius dapat lebih kreatif dalam pemben-tukan kepribadian Islami dan akhlak mulia; (3) pada praktis, (a) apabila penanaman nilai-nilai dasar humanis religius bagi anak usia dini keluarga perkotaan akan ditingkatkan, agar memperoleh hasil yang optimal, maka perlu dirancang lebih khusus, dengan memasukkan pada kurikulum tingkat satuan pendidikan, yaitu: dengan menetapkan bab dan subbab, penanaman nilai-nilai dasar humanis religius, dengan metode yang sesuai, perlu mencoba metode kreatif yang lain, yang sesuai dengan perkembangan anak, situasi, dan kondisi kekinian, (b) TK IT Full Day School Mu'adz bin Jabal yogyakarta perlu melanjutkan pelatihan-pelatihan (workshop) dalam merancang penanaman nilai-nilai dasar humanis religius dengan pelaksanaan lebih kreatif dan inovatif, tanpa mengesampingkan tugas pokok lembaga terhadap proses belajar mengajar yang sifatnya rutin, intelektual, dan psikomotorik, (c) apabila dikehendaki penghayatan nilai-nilai dasar humanis religius atau semakin kuat terinternalisasi pada anak diri anak, sehingga memunculkan keinginan lebih kuat, mengakar pada perilaku sehari-hari, serta dapat diapresiasi oleh pihak lain, maka pengembangan penanaman nilai-nilai dasar humanis religius bagi anak usia dini perkotaan dapat dijadikan silabi atau buku pegangan guru, dan disebarluaskan sehingga produktif secara ekonomis; (4) pada pembuatan kebijaksanaan pendidikan, penanaman nilai-nilai dasar humanis religius bagi anak usia dini memerlukan dukungan dalam kebijaksanaan. Maka perlu dukungan institusi pendidikan yang relevan, misalnya Mapenda Kementerian Agama Republik Indonesia di Kota Yogyakarta, Dinas Pendidikan Kota Yogyakarta, dan organisasi Islam yang peduli pada pendidikan anak usia dini, untuk menjadikan hasil penelitian ini sebagai masukan atau pertimbangan dalam menentukan kebijakan, khususnya kebijakan pendidikan nilai anak usia dini keluarga perkotaan. Diperlukan pengelolaan dan pengembangan sumber daya manusia, seperti; Kamapenda Kemenag Kota Yogyakarta, Pengawas TK-SD di tingkat kecamatan, kepala sekolah TK, guru TK, tenaga administrasi dan K3, di masing-masing lembaga pendidikan jenjang TK kota Yogyakarta dan sekitarnya.

\section{DAFTAR PUSTAKA}

Achmadi. (2010). Ideologi pendidikan Islam. Paradigma humanis teosentris. Yogyakarta: Pustaka Pelajar.

Alquran. (2001). Alquran dan terjemahannya. Transiterasi Arab-Latin. Semarang: CV.Asy Syita.

Barnadib, Imam (1967). Filsafat pendidikan: Sistem dan metode. Yogyakarta: Andi Offset.

Bloom, Benyamin. S. (1956). Taxonomy of education objectives. Hanbook 1. Cognitive Domain. New York: Longman Inc.

Bredekamp, S. (1987). Developmentally appropriate practices, serving education for young children from birth through age eight. Washinton, DC: NAEYC.

Cryan, K. (1992). Character development. Washington DC: The Council for Research in Value and Philosphy.

Delors, J. (1997). Learning the treasure within. Pans: UNESCO.

Driyarkara. (1991). Driyarkara tentang Pendidikan. Yogyakarta: Kanisius.

Elmubarok, Zaim. (2008). Membumikan pendidikan nilai. Bandung: Alfabeta.

Instruksi Presiden RI. (2009). Pendidikan budaya dan karakter bangsa melalui pembelajaran aktif. Jakarta: Dirjen PAUD.

JSIT. (2010). Standar mutu sekolah Islam terpadu. Jakarta: JSIT Indonesia. 
166 Jurnal Pembangunan Pendidikan: Fondasi dan Aplikasi Volume 2, Nomor 2, 2014

Martuti. (2008). Mengelola PAUD dengan aneka permainan meraih kecerdasan majemuk. Yogyakarta: Kreasi Wacana.

Masruri. (2010). Negatif learning. Solo: Era Adicitra Intermedia.

Mudjib, Abdul. (1999). Fitrah dan kepribadian Islam. Jakarta: Darul Fallah.

Muhadjir, Noeng. (2011). Metode penelitian. Edisi VI Pengembangan. Yogyakarta: Sarasin.

Nata, Abudin. (2010). Ilmu pendidikan Islam. Jakarta: Kencana Prenada Media Group.

Siskandar. (2003). Menu pembelajaran generik.Jakarta: Buletin PAUD 2003. Dirjen Pendidikan Luar Sekolah dan Pemuda.

Sudjud, Aswarni. (1998). Paradigma anak usia dini. Yogyakarta: IKIP. Yogyakarta.

Sugiyono. (2008). Metode penelitian pendidikan: Pendekatan kuantitatif, kualitatif dan $R \& D$. Bandung: Alfabeta.

Sulistyaningsih, Wiwik. (2008). Full day school dan optimalisasi perkembangan.
Suseno, Magnis. (2009). Etika Jawa. Jakarta: Gramedia.

Tangdilintin, P. (1990). Pengaruh tiga adicita modernisasi terhadap keluarga dan ekonomi keluarga perkotaan. Disertasi Doktor, tidak diterbitkan. Jakarta. UI.

UU RI No 20. (2003). Sistem pendidikan nasional. Amandemen. Jakarta: Sinar Grafika.

Yusuf, Syamsu \&.Nurihsan. (2008). Psikologi perkembangan anak \& remaja. Bandung: Remaja Rosdakarya.

Zuchdi, Darmiyati. (2010). Humanisasi pendidikan: menemukan kembali pendidikan yang manusiawi. Jakarta: Bumi Aksara.

Zuchdi, D., Prasetya, Z. K., \& Masruri, M. S.. (2013). Model pendidikan karakter terintegrasi dalam pembelajaran dan pengembangan kultur sekolah. Yogyakarta: Multi Presindo.

Zulkarnain. (2008). Transformasi nilai-nilai pendidikan Islam, manajemen berorientasi link and match. Yogyakarta: Pustaka Pelajar. 